\title{
ADSORPTION ENERGY CALCULATIONS FOR AI ATOM ON STEPPED SILICON SURFACE
}

\author{
E. Žąsinas, J.V. Vaitkus, and V. Pažūsis \\ Institute of Materials Science and Applied Research, Vilnius University, Saulètekio 9, LT-10222 Vilnius, Lithuania \\ E-mail: ernestas.zasinas@ff.vu.lt
}

Received 10 September 2007; revised 27 September 2007; accepted 21 November 2007

\begin{abstract}
We have computed adsorption (binding) energy of $\mathrm{Al}$ atom over the various points of the stepped $\mathrm{Si}(332)$ surface and have built potential energy map as seen by $\mathrm{Al}$ adatom over the surface. The binding energy of adatom was found to be the largest over two broad regions in the middle of terrace and having the values of $-5.66 \mathrm{eV}$ and $-5.42 \mathrm{eV}$. Such broad potential minima form two valleys where the adatom may diffuse along the terrace overcoming energy barriers of $0.2 \mathrm{eV}$. Meanwhile, the activation energy needed for the adatom to diffuse from one terrace to another is $2.14 \mathrm{eV}$. It is expected that $\mathrm{Al}$ adatoms diffuse along these valleys during epitaxial growth before slowing down and attaching themselves to the terrace steps. In the vicinity of terrace step the adsorption energy calculated taking into account additional relaxation of surface $\mathrm{Si}$ atoms due to interaction with $\mathrm{Al}$ adatom has the value of $-5.67 \mathrm{eV}$. Calculations of the relaxation of the stepped $\mathrm{Si}(332)$ surface and of adsorption energies of $\mathrm{Al}$ adatom were performed in the framework of density functional theory.
\end{abstract}

Keywords: energy band gap adsorption, vicinal surface, surface diffusion

PACS: 68.43.-h, 68.35.Bs, 68.35.Fx

Formation of periodically ordered nanoscale atomic structures is among the goals of modern technology. Potential tool for achieving this goal is the use of stepped crystalline surface as a template for selforganized growth of periodic atomic clusters or onedimensional chains. According to the classical model of crystal growth during a constant flux of atoms they overpass the surface terraces and are adsorbed there. That was demonstrated experimentally [1]. At relatively high temperatures adatoms can diffuse on the terraces until they are desorbed back to the gas or approach a step edge where they are captured and localized. At intermediate temperatures the formation of atomic islands occurs when few adatoms meet together. If one chooses the sort of adatoms which will crystallize into material having very different lattice constant compared to the substrate one, then one may expect that adatomic islands will not coalesce into homogenous overlayer. This was a basic idea succesfully applied earlier to grow nanoclusters of $\mathrm{PbS}, \mathrm{CdSe}$, and $\mathrm{ZnSe}$ on Si surface [2]. Recently much of experimental and computational effort is devoted to the study of metallic element atom adsorption. Usually metal atom impurities are used to form the deep enegy levels in the band gap of bulk semiconducors. For the same rea- son it is expected that the nanosize formations of metal atoms could lead to a narrow bunch of energy levels or even band (in case of nanowires) deep in the energy band gap of a semiconductor. That would suggest many new interesting opportunities for inventing new optoelectronic devices.

In order to get a deeper understanding of epitaxial growth of metal clusters, we have chosen to study $\mathrm{Al}$ atom behaviour on a stepped Si surface. A stepped silicon surface $\mathrm{Si}(332)$ was chosen as a substrate. $\mathrm{Si}(332)$ surface is vicinal to $\mathrm{Si}(111)$ plane. It has about $10 \mathrm{de}$ grees slope and contains five atoms across the terrace width, as shown in Fig. 1. To model crystalline surface one takes a superlayer of few atomic layers and a vacuum region. Such a superlayer is periodic both in

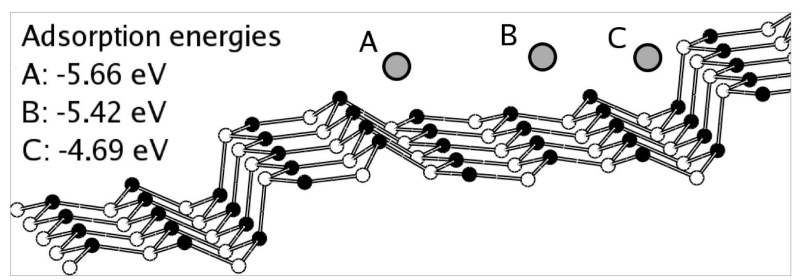

Fig. 1. A stepped $\mathrm{Si}(332)$ surface and $\mathrm{Al}$ atoms above it. Si atoms from different layers are shown as white and black balls, $\mathrm{Al}$ atom as a gray ball. Al atom is shown at three different lateral positions where its binding energy has local minima (see also Fig. 3). 


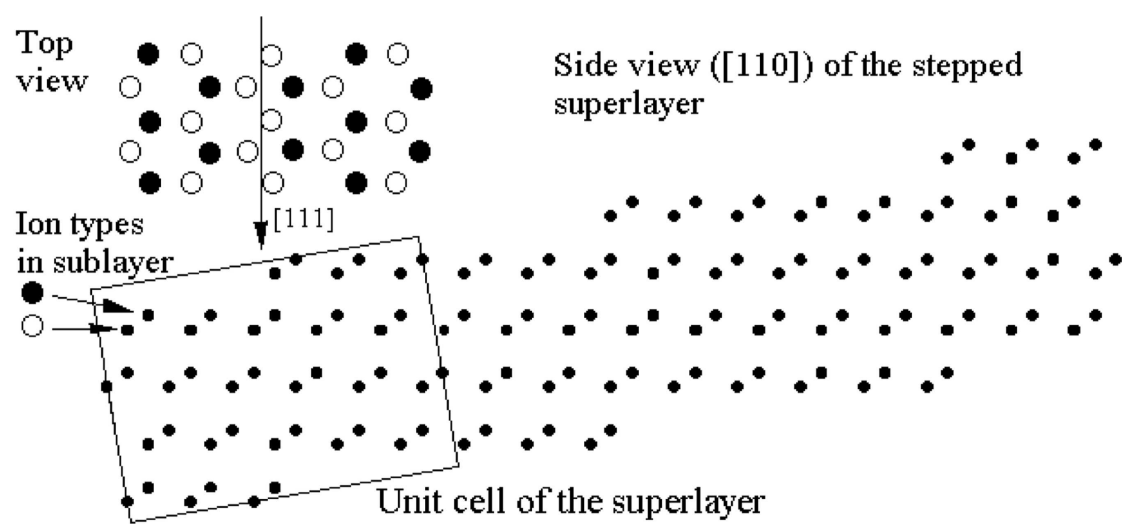

Fig. 2. A superlayer used to model stepped Si(332) surface. Steps are formed by cutting flat (111) surface with the (332) plane. Unit cell contains $44 \mathrm{Si}$ atoms.

perpendicular and parallel to the surface directions. An elementary supercell of thus chosen superlayer in our case contains $44 \mathrm{Si}$ atoms and is shown in Fig. 2.

At first we performed calculations to find the relaxed equillibrium atomic positions of the surface. Only four atomic monolayers at the boundary with vacuum were allowed to relax. The equillibrium configuration of the relaxed surface atoms is shown in Fig. 3. Computation of relaxed structure was performed until convergence of atomic forces to the value of $0.1 \mathrm{eV} / \AA$ was reached.

Then we approached $\mathrm{Al}$ atom to such a relaxed surface at the surface point $(x, y)$ and, by altering its distance to the surface, were looking for the minimum total energy of the system. Knowing this minimal energy of $\mathrm{Al}+\mathrm{Si}(332)$ system we subtracted energies of separate $\mathrm{Al}$ atom and $\mathrm{Si}(332)$ surface and thus obtained adsorption (binding) energy of $\mathrm{Al}$ atom at the surface point $(x, y)$.

To calculate a total energy of the atomic system we applied density functional theory and used computer code fhi96md [3]. The exchange-correlation potential was taken after Ceperley-Alder [4], the electron-ion interactions were described by pseudopotentials given in [5]. The electronic wave functions were expanded in a plane wave basis set with the kinetic energy cutoff equal to $20 \mathrm{Ry}$. Due to a large amount of com-

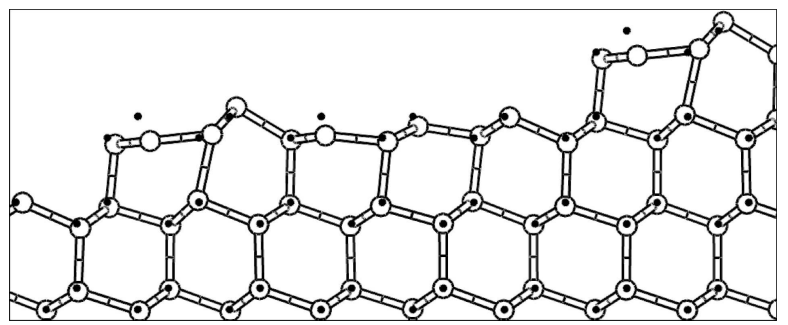

Fig. 3. Equilibrium positions of relaxed surface layer atoms. The initial positions of $\mathrm{Si}$ ions at the ideal crystalline lattice points are shown by black dots. putations we had to simplify our calculations. Usually density functional calculations are performed until convergence of the Kohn-Sham equations is reached. We did this procedure only twice. At first it was done in the calculations of surface relaxation. Then, in order to obtain the adsorption energies at various points of adatom above the surface, we simplified the calculations as follows: electron density was not calculated self-consistently but was obtained from the atomic orbitals in tight-binding approximation and was further used to calculate the total energy of the system. By doing this one can obtain only an approximate form of the adsorption energy map - define its minima, saddle, and maxima points, but not the exact energy values. After these calculations we found that the largest binding energy of $\mathrm{Al}$ adatom is at the point $A(x, y)=(1.91$, 2.15) (in $\AA$ ) in the middle of the terrace (Figs. 1 and $3)$. Only for this point we then performed full electron density convergence calculations and obtained the binding energy value of $-5.66 \mathrm{eV}$. Then we shifted already obtained adsorption energies at the other $(x, y)$ points in such a way that the energy map had an absolute minimum at the point $A$ with the binding energy of $-5.66 \mathrm{eV}$. In addition, the further relaxation of surface silicon atoms due to interaction with $\mathrm{Al}$ adatom was not taken into account. Therefore the results of such a simplified calculation are valid only at high temperatures when the kinetic energy of adatom is large and it moves fast on top of the surface without stopping anywhere and has not enough time to induce significant surface structure changes. Thus obtained adsorption energy map is shown in Figs. 4 and 5.

Such a map of adsorption energy can be treated as a potential energy surface for $\mathrm{Al}$ adatom above the $\mathrm{Si}(332)$ surface. It tells us that during epitaxial growth $\mathrm{Al}$ atoms most likely will condense at the places of potential energy minima at the points $A(x, y)=$ 
(a)

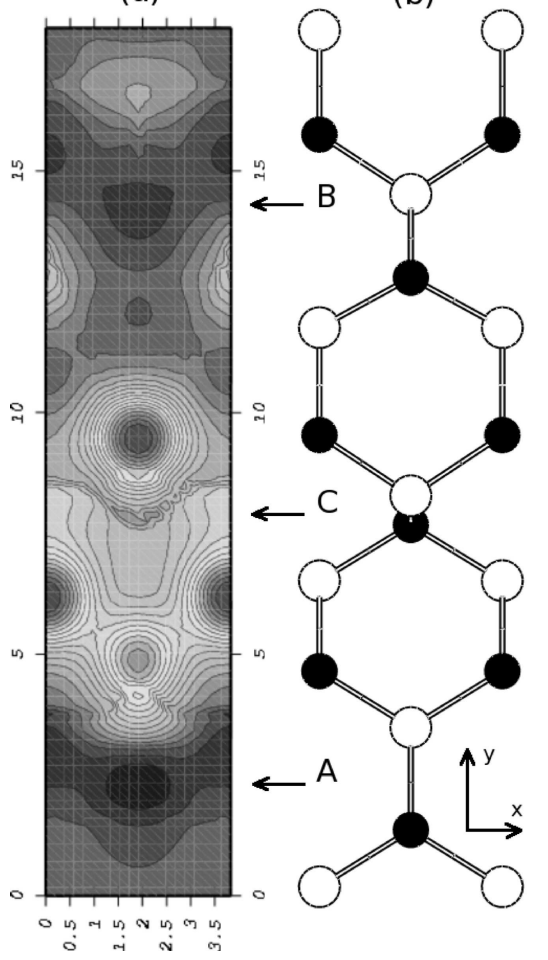

(c)

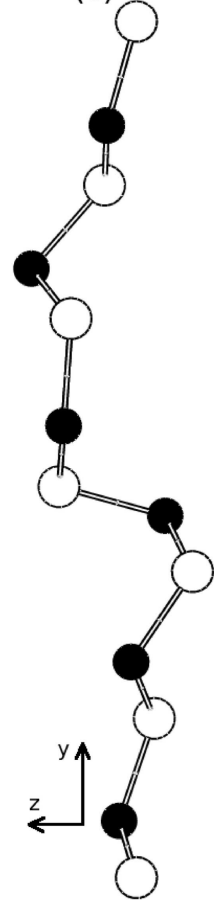

Fig. 4. (a) A map of adsorption energy of $\mathrm{Al}$ atom over the $\mathrm{Si}(332)$ surface. $x$ and $y$ axes are $\mathrm{Al}$ atom coordinates in $\AA$ with respect to the $\mathrm{Si}$ atom at the bottom left corner in the panel (b). The darkest regions correspond to the largest binding energy. (b) and (c) are the top and side views of the $\mathrm{Si}(332)$ surface atoms. The terrace step is at $y=8 \AA$. All three pictures should be imagined periodic in $x$ and $y$ directions. Lattice periods are 3.84 and $17.99 \AA$ in $x$ and $y$ directions respectively.

$(1.91,2.15), B(x, y)=(1.91,14.18)$, and $C(x, y)=$ $(0.96,8.44)$ (in $\AA$ ) with adsorption energies $-5.66 \mathrm{eV}$, $-5.42 \mathrm{eV}$, and $-4.69 \mathrm{eV}$ respectively. Potential wells at $A$ and $B$ points are localized in the middle of the terrace and have close binding energy values. It is expected that at these points atoms attach themselves to the surface and initiate an island formation in the mid- dle of terrace or at the step in the case of point $C$. Both potential minima at $A$ and $B$ points are broadly extended and form some sort of valleys, where the adatom may diffuse along the terraces overcoming $0.2 \mathrm{eV}$ energy barriers. In contrast, to diffuse up or down to the next terrace the atom has to overcome $2.1 \mathrm{eV}$ energy barrier.

Another feature of potential energy surface is a sharp adsorption energy minimum located in the vicinity of the terrace step at the point $C$. Unlike the energy minima at $A$ and $B$ points the minimum around $C$ point is localized and may form the suitable spot where the atom may attach itself. To check whether this could really happen at low temperatures, when the adatom looses its kinetic energy and may stay for a longer time to induce the structure changes of the surface atoms, we have performed one more self-consistent calculation allowing the silicon atoms in the vicinity of $\mathrm{Al}$ atom to relax. In that case the adsorption energy is significantly lowered, contrary to the case when the surface silicon atoms are fixed, and now has the value of $-5.67 \mathrm{eV}$. As illustrated in Fig. 6, Al atom in this case comes into strong covalent binding with the edge silicon atoms.

This energy value has to be compared with the adsorption energy at the point $A$ in the middle of the terrace step computed again taking into account relaxation of the surface atoms due to interaction with $\mathrm{Al}$ atom. Now the situation changes to the opposite: the adsorption energy in the middle of the terrace is $-5.51 \mathrm{eV}$, which means that here the adatom and surface bond is weaker than at the terrace step where adsorption energy is $-5.67 \mathrm{eV}$ (recall that the values of adsorption energies have been $-5.66 \mathrm{eV}$ in the middle of terrace and $-4.69 \mathrm{eV}$ at the edge of terrace without taking into account $\mathrm{Si}$ atoms interaction with $\mathrm{Al}$ adatom). Therefore as a conclusion we suggest that the reconstruction of the crystal lattice is an important factor for the adatom

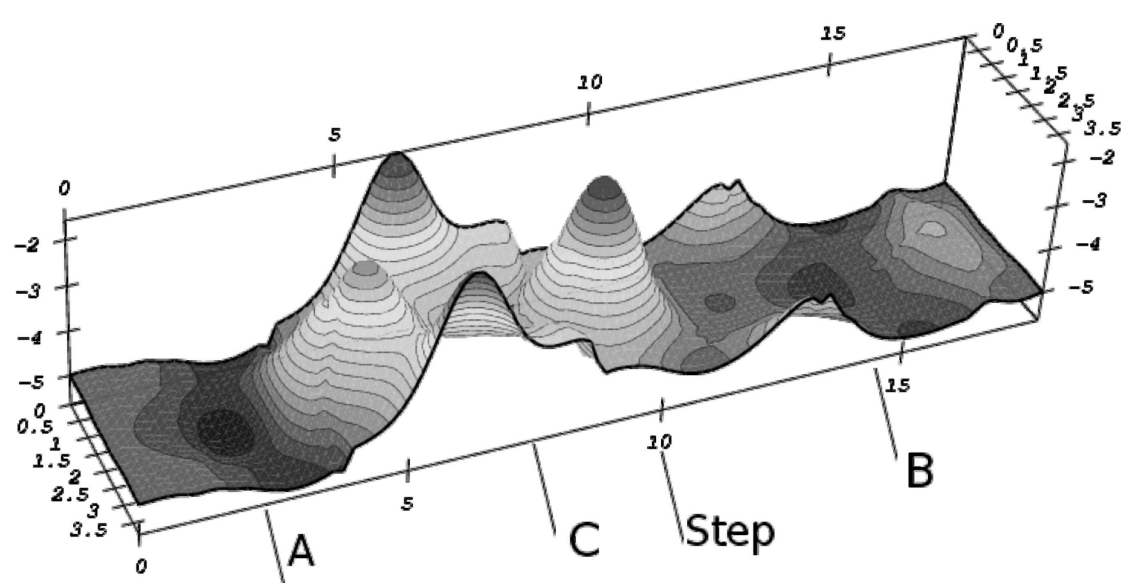

Fig. 5. Three-dimensional image of adsorption energy map. 


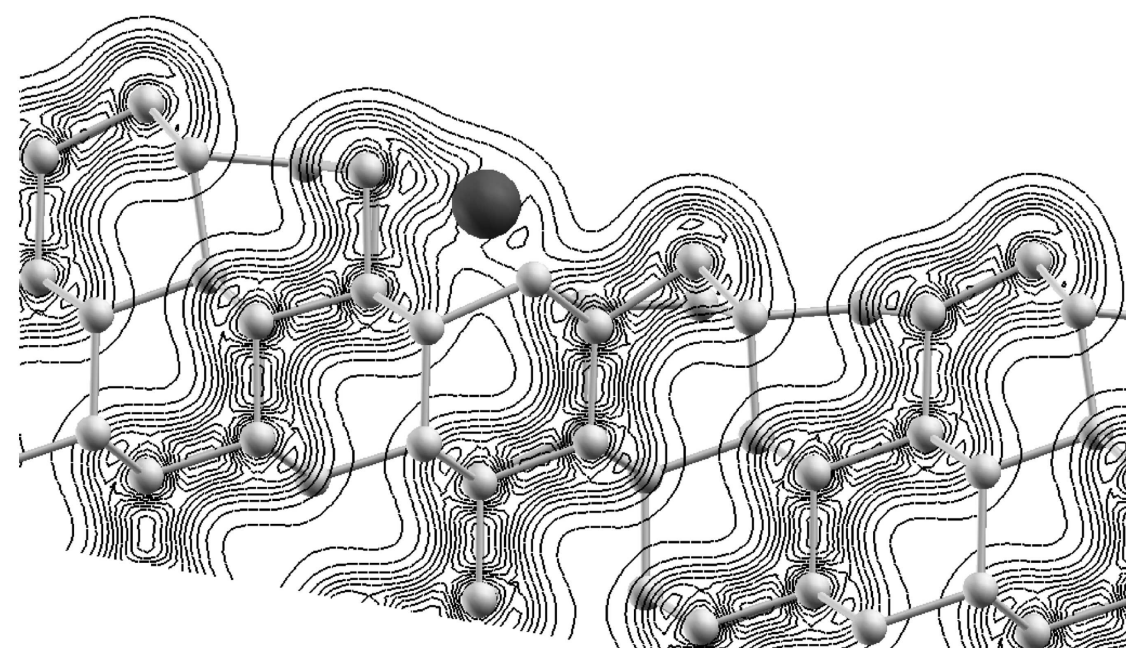

Fig. 6. Electron density contour map in the plane also containing an $\mathrm{Al}$ atom.

migration on the terrace to the terrace step, as it has been experimentally demonstrated in [1].

\section{Acknowledgements}

This work was supported by the Lithuanian State Science and Studies Foundation. Part of computations were performed on the Lithuanian Grid computing facilities.

\section{References}

[1] J.L. Batstone and C. Heyzelden, Solid State Phenom. 37-38, 257 (1994).

[2] J. Vaitkus, R. Baubinas, E. Gaubas, V. Kazlauskiene, J. Miskinis, A. Mazeikis, J. Sinius, E. Zasinas, and A. Zindulis, Microelectron. J. 30, 335 (1999).

[3] M. Bockstedte, A. Kley, J. Neugebauer, and M. Scheffler, Comput. Phys. Commun. 107, 187 (1997).

[4] D.M. Ceperley and B.J. Alder, Phys. Rev. Lett. 45, 567 (1980).

[5] G.B. Bachelet, D.R. Hamman, and M. Schluter, Phys. Rev. B 23, 5048 (1980).

\title{
ALIUMINIO ATOMO ADSORBCIJOS ANT LAIPTUOTO SILICIO PAVIRŠIAUS ENERGIJOS APSKAIČIAVIMAS
}

\author{
E. Žąsinas, J.V. Vaitkus, V. Pažūsis
}

Vilniaus universiteto Medžiagotyros ir taikomuju mokslu institutas, Vilnius, Lietuva

\section{Santrauka}

Pasitelkus tankio funkcionalo teoriją apskaičiuota aliuminio atomo adsorbcijos (ryšio) energija virš įvairių laiptuoto kristalinio silicio paviršiaus $\mathrm{Si}(332)$ vietų. Iš gautų energijos verčių sudarytas dvimatis paviršiaus žemėlapis, vaizduojantis potencinị lauką, kuriame juda $\mathrm{Al}$ atomas, sąveikaujantis su kristalo paviršiumi. Didžiausia ryšio energija $(-5,66$ ir $-5,42 \mathrm{eV})$ buvo gauta, kai atomas yra plačiose srityse terasos viduryje. Čia susidaro potencinès energijos slèniai, kuriuose epitaksinis atomas gali difunduoti išilgai terasos, iveikdamas $0,2 \mathrm{eV}$ aukščio energijos barjerus. Tuo tarpu aktyvacijos energija, būtina atomui peršokti nuo vieno terasos laiptelio ant kito, yra 2,14 eV dydžio. Vykstant epitaksinio auginimo procesui $\mathrm{Al}$ atomai difunduoja išilgai terasų, kol praranda kinetinę energiją ir prilimpa prie terasos laiptelio. Iskaičius paviršiaus silicio atomu relaksaciją dèl sąveikos su $\mathrm{Al}$ atomu, ryšio energijos vertè šioje vietoje yra $-5,67 \mathrm{eV}$. 